\title{
Meningkatkan Pengetahuan Masyarakat Dalam Perbaikan Sanitasi Lingkungan
}

\author{
L.M. Azhar Sa'ban' ${ }^{*}$, Anwar Sadat ${ }^{2}$, Asrul Nazar ${ }^{3}$ \\ 1, 2 Program Studi Ilmu Pemerintahan, Fakultas Ilmu Sosial dan Ilmu Politik \\ ${ }^{3}$ Program Studi Pendidikan dan Sastra Indonesia, Fakultas Keguruan dan Ilmu Pendidikan \\ Universitas Muhammadiyah Buton \\ *e-mail. $\underline{\text { izharrazi@gmail.com }{ }^{1} \text { anwarsadat685@gmail.com }{ }^{2} \text {, asrulnazar@gmail.com³ }}$
}

\begin{abstract}
This community service program is carried out in Mulyajaya Village, Lasalimu Selatan District, Buton Regency. Some of the main problems that become a problem in Mulyajaya Village, Lasalimu Selatan District, Buton Regency, are the not yet optimal knowledge of the community regarding Environmental Sanitation and the lack of optimal socialization to the public about how to create and improve a healthy environment. The results of this PKM activity can be described through the role of social capital as a form of local knowledge, it can be used as a means of socializing the importance of environmental awareness. The process of increasing community knowledge about environmental improvement is carried out through three discussions namely socialization, mentoring and planning for making garbage cans and making latrines.
\end{abstract}

Keywords: Environmental Sanitation and Social Capital

\begin{abstract}
Abstrak
Program pengabdian masyarakat ini dilakukan di Desa Mulyajaya Kecamatan Lasalimu Selatan Kabupaten Buton. Beberapa masalah pokok yang menjadi masalah di Desa Mulyajaya Kecamatan Lasalimu Selatan Kabupaten Buton sekaligus yaitu belum optimalnya pengetahuan masyarakat mengenai pentingnya Sanitasi Lingkungan dan belum optimalnya sosialisasi kepada masyarakat perihal bagaimana menciptakan dan meningkatkan lingkungan yang sehat. Hasil kegiatan PKM ini dapat dideskripsikan melalui peran modal sosial masyarakat sebagai bentuk pengetahuan lokal, dapat dimanfaatkan sebagai sarana mensosialisasikan pentingnya kesadaran akan sanitasi lingkungan. Proses meningkatkan pengetahuan masyarakat dalam perbaikan sanitasi lingkungan dilaksanakan melalui tiga pendekatan yaitu sosialisasi, pendampingan dan perencanaan pembuatan tong sampah dan pembuatan jamban.
\end{abstract}

Kata kunci: Sanitasi Lingkungan, Modal Sosial

\section{PENDAHULUAN}

Lingkungan yang baik dan sehat merupakan suatu hal yang sangat penting dalam menunjang kelangsungan hidup manusia. Lingkungan merupakan segala sesuatu yang ada di sekitar kita, baik hidup maupun tidak, seperti udara, air, tanah dengan segala yang ada di atasnya seperti tumbuhan, hewan, mikroorganisme (Suanta, 2016). Manusia diberi hak untuk memanfaatkan, tetapi juga mempunyai tanggung jawab untuk melindungi dan melestarikan lingkungan agar semakin hari semakin baik dan sehat. Namun, kenyataan yang kita hadapi saat ini adalah terjadinya kerusakan lingkungan karena kurang tertanamnya karakter peduli lingkungan pada manusia.

Peduli lingkungan adalah sikap atau tindakan yang berupaya mencegah kerusakan pada lingkungan alam di sekitarnya dan mengembangkan upaya-upaya untuk memperbaiki kerusakan alam yang terjadi. Karakter peduli lingkungan bukanlah sepenuhnya talenta maupun insting bawaan, akan tetapi merupakan hasil dari suatu proses pendidikan dalam arti luas. Kepedulian lingkungan merupakan wujud sikap mental individu yang direfleksikan dalam perilakunya (Ramadhani et al., 2019). Lingkungan juga bisa diartikan sebagai segala sesuatu yang terdapat di sekitar manusia kemudian tinggal bersama dan saling mempengaruhi bagi perkembangan kehidupan manusia. 
Sanitasi disini adalah upaya yang dilakukan untuk merubah prilaku budaya hidup bersih dan sehat dengan tidak buang air besar sembarangan, mencuci tangan pakai sabun, mengelola air minum dan makanan yang aman, mengelola sampah rumah tangga dengan aman dan mengelola limbah cair rumah tangga dengan aman.

Sanitasi adalah prilaku disengaja dalam pembudayaan hidup bersih dengan maksud mencegah manusia bersentuhan langsung dengan kotoran dan bahan buangan berbahaya lainnya dengan harapan usaha ini akan menjaga dan meningkatkan kesehatan manusia (Ismail, 2010). Jadi penegrtian sanitasi lingkungan adalah status kesehatan suatu lingkungan yang mencakup perumahan, pembuangan ketoran, penyediaan air bersih dan sebagainya (Notoatmodjo, 2003).

Sanitasi lingkungan merupakan suatu usaha untuk mencapai lingkungan sehat melalui pengendalian faktor lingkungan fisik, khususnya hal-hal yang memiliki dampak merusak perkembangan fisik kesehatan dan kelangsungan hidup manusia. Sanitasi lingkungan mempunyai kedudukan yang paling penting dalam kehidupan sehari-hari, karena berpengaruh terhadap kesehatan seseorang dan masyarakat. Sanitasi lingkungan dapat mencerminkan tata cara hidup dari masyarakat tersebut. Untuk mendapatkan kondisi sanitasi lingkungan yang baik sangat bergantung dari tata cara dan perilaku masyarakat di dalam memelihara kualitas sanitasi lingkungannya.

Sanitasi merupakan salah satu komponen dari kesehatan lingkungan, yaitu perilaku yang disengaja untuk membudayakan hidup bersih untuk mencegah manusia bersentuh langsung dengan kotoran dan bahan buangan berbahaya lainnya, dengan harapan dapat menjaga dan meningkatkan kesehatan manusia (Prasanti \& Fuady, 2017).

Lingkungan yang bersih menjadi sebuah cerminan bagi setiap individu dalam menjaga kesehatan jasmani dalam kehidupan sehari-hari. Program perilaku hidup bersih dan sehat adalah salah satu upaya promosi kesehatan yang bertujuan agar setiap orang dapat tinggal di lingkungan yang bersih dan sehat dengan menciptakan suatu kondisi yang kondusif bagi perorangan, keluarga, kelompok dan masyarakat. Hal ini bertujuan untuk meningkatkan pengetahuan, sikap dan perilaku agar dapat menerapkan cara-cara hidup sehat dalam rangka menjaga, memelihara, dan meningkatkan kesehatan (Rahman \& Patilaiya, 2018).

Dari defenisi diatas, tampak bahwa sanitasi lingkungan ditujukan untuk memenuhi persyaratan-persyaratan lingkungan yang sehat dan nyaman. Lingkungan yang sanitasinya buruk dapat menjadi sumber berbagai macam penyakit yang dapat mengganggu kesehatan manusia. Pada akhirnya jika kesehatan terganggu, maka kesejahteraan juga akan berkurang. Satu hubungan yang sangat dinamis antara manusia dan lingkungannya, dapat dilihat dari bagaimana cara manusia hidup bersama, berdampingan dengan semua komponen di sekitarnya (Desfandi, 2015).

Berdasarkan observasi yang dilakukan di Desa Mulyajaya Kecamatan Lasalimu Selatan, kesadaran masyarakat terhadap lingkungan sangatlah minim, berdasarkan hal tersebut dapat diprediksi bahwa masyarakat masih belum peduli terhadap kebersihan lingkungan sekitarnya. Kebanyakan dari masyarakat berfikir secara persial dan hanya ingin menguntungkan diri sendiri, seperti masalah pembuangan sampah yang tidak pada tempatnya, pembuangan limbah rumah tangga dan lain-lain.

Kasus-kasus yang menyangkut masalah kebersihan setiap tahunnya selalu meningkat, dan mengakibatkan keadaan yang merugikan seperti banyaknya sampah yang menumpuk di titik-titik tertentu dan saluran air yang bisa menyebabkan banjir karena meluapnya air yang tidak tertampung, untuk itu kepedulian masyarakat sangat dibutuhkan tidak hanya pemerintah setempat yang harus menanggungnya. 

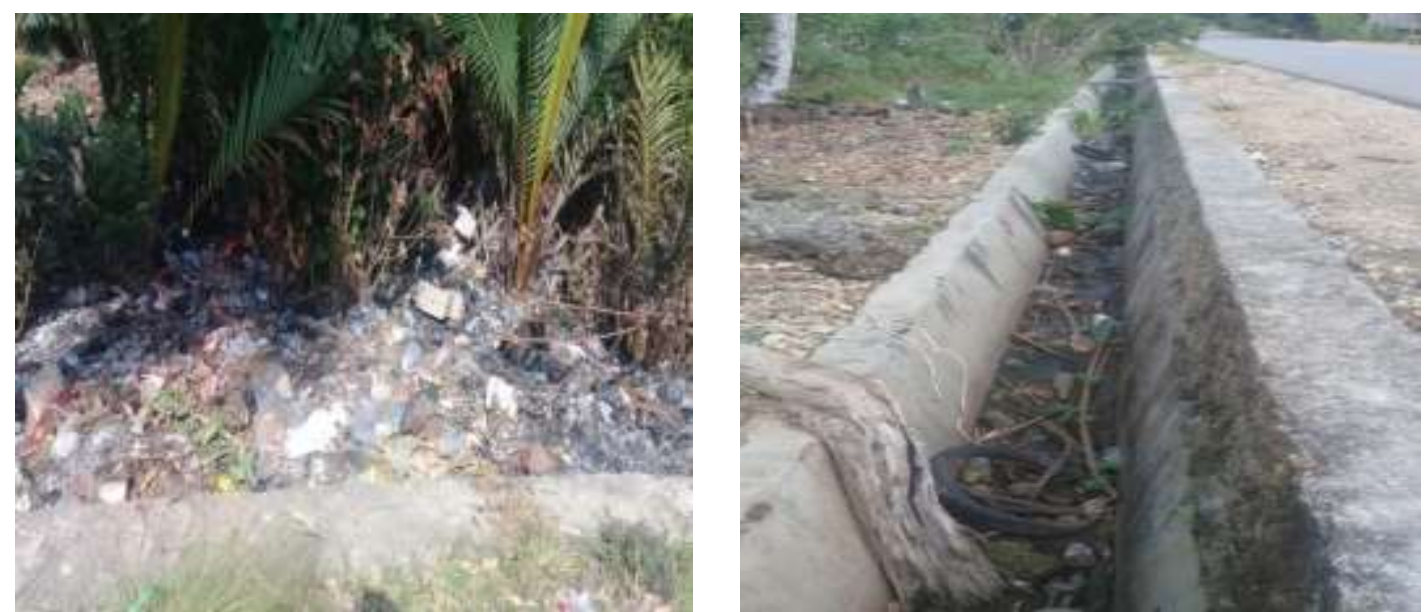

Gambar 1. Saluran Drainase dan Tempat Pembuangan Sampah Desa Mulyajaya

Dapat dilihat pada gambar diatas bahwasanya kondisi lingkungan di Desa Mulyajaya sangat memprihatinkan. Saluran drainase yang sudah tersumbat akibat tertumpuknya sampah dan pembuangan sampah yang bukan pada tempatnya yang menyebabkan pencemaran udara akibat bau busuk. Sanitasi lingkungan seperti gambar diatas dapat mengundang munculnya berbagai penyakit, dapat dilihat dengan masih adanya masyarakat yang belum mempraktekan perilaku hidup sehat, seperti mebuang sampah sembarangan, hal ini juga dapat menyebabkan banjir.

Kesadaran masyarakat terhadap lingkungan sangatlah minim, berdasarkan hal tersebut dapat diprediksi bahwa masyarakat masih belum peduli terhadap kebersihan lingkungan sekitarnya. Kebanyakan dari masyarakat berfikir secara parsial dan hanya ingin menguntungkan diri sendiri, seperti masalah pembuangan sampah yang tidak pada tempatnya, pembuangan limbah rumah tangga, pencemaran air, dan lain-lain. Kasus-kasus yang menyangkut masalah kebersihan setiap tahunnya selalu meningkat, dan mengakibatkan keadaan yang merugikan seperti banyaknya sampah yang menumpuk di titik-titik tertentu dan saluran air yang bisa menyebabkan banjir karena meluapnya air yang tidak tertampung, untuk itu kepedulian masyarakat sangat dibutuhkan tidak hanya pemerintah setempat yang harus menanggungnya.

Untuk mencapai kondisi masyarakat yang hidup sehat dan sejahtera di masa yang akan datang, akan sangat diperlukan adanya lingkungan permukiman yang sehat. Dari aspek persampahan, maka kata sehat akan berarti sebagai kondisi yang akan dapat dicapai bila sampah dapat dikelola secara baik sehingga bersih dari lingkungan permukiman dimana manusia beraktifitas di dalamnya (Suryani et al., 2019).
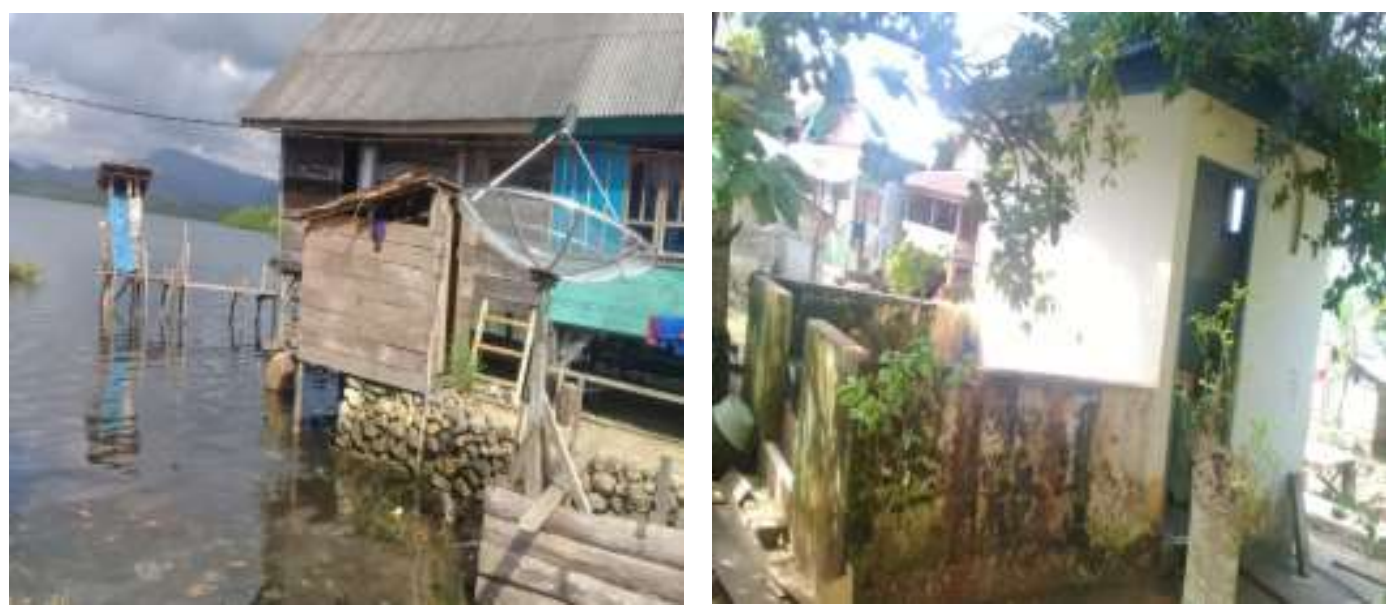

Gambar 2. Jamban warga dan WC Umum Desa Mulyajaya 
Pada gambar di atas masalah sanitasi terutama toilet dan WC umum masih perlu dibenahi. Toilet harus dibuat nyaman, maka secara tidak langsung toilet tersebut tak hanya layak pakai, namun juga sehat karena terjaga kebersihannya.

Kesadaran masyarakat dalam hal ini menjadi penting, karena kesadaran masyarakat adalah proses yang diawali dari adanya rasa memiliki, yaitu rasa memiliki lingkungan sekitar yang akan memicu rasa tanggung jawab. Rasa tanggung jawab ini akan menghasilkan kesadaran warga bahwa tugas untuk menjaga lingkungan bukan hanya kewajiban pemerintah saja tapi juga warganya. Mengingat tentang kesadaran tersebut, perlu di ketahui juga bahwa bencana seperti banjir, longsor, dan meluapnya air dikarenakan ketidak pedulian masyarakat itu sendiri.

Aspek sanitasi lingkungan sangat luas cakupannya bahkan hampir di sebagian besar kehidupan manusia. WHO telah membuktikan melalui penelitiannya di seluruh dunia dengan menghasilkan data bahwa angka kematian (mortalitas), angka kematian orang sakit (morbiditas) serta seringnya terjadi epidemi ditemukan di tempat-tempat yang kondisi hygiene dan sanitasi lingkungannya buruk, seperti banyak sampah menumpuk, lalat, nyamuk, kondisi air yang buruk, keadaan sosial ekonomi yang jelek. Dengan demikian, sanitasi lingkungan sangat penting untuk mencegah berbagai timbulnya penyakit dengan memutus atau mengendalikan faktor lingkungan yang menjadi mata rantai penularan penyakit (Rahmawati et al., 2018).

Kesehatan lingkungan yang merupakan bagian dari pada kesehatan masyarakat pada umumnya, mempunyai tujuan membina dan meningkatkan derajat kesehatan dari kehidupan sehari-hari, baik fisik, mental, maupun sosial dengan cara pencegahan terhadap penyakit dan gangguan kesehatan. Masalah kebersihan lingkungan di Desa Mulyajaya masih memerlukan peningkatan dalam menanggulangi masalah tersebut, karena di Desa Mulyajaya, masalah kebersihan lingkungan masih kurang memenuhi harapan.

Peduli lingkungan didefinisikan sebagai sikap dan tindakan yang selalu berupaya mencegah kerusakan pada lingkungan alam di sekitarnya dan mengembangkan upaya-upaya Peduli lingkungan didefinisikan sebagai sikap dan tindakan yang selalu berupaya mencegah kerusakan pada lingkungan alam di sekitarnya dan mengembangkan upaya-upaya (Purwanti, 2017). Program Perilaku Hidup Bersih dan Sehat (PHBS) adalah salah satu upaya promosi kesehatan yang bertujuan agar setiap orang dapat tinggal di lingkungan yang bersih dan sehat dengan menciptakan suatu kondisi yang kondusif bagi perorangan, keluarga, kelompok dan masyarakat. Hal ini bertujuan untuk meningkatkan pengetahuan, sikap dan perilaku agar dapat menerapkan cara-cara hidup sehat dalam rangka menjaga, memelihara, dan meningkatkan kesehatan (Raksanagara \& Raksanagara, 2016).

Untuk membangun masyarakat berkarakter peduli lingkungan, salah satunya melalui bidang pendidikan. Seperti kita ketahui, pendidikan merupakan salah satu aspek yang dapat mempengaruhi dunia masa depan dan merupakan cara yang paling efektif dalam membentuk masyarakat yang memiliki kemampuan untuk menghadapi tantangan di masa depan. Pendidikan menjadi dasar bagi tindakan dan penting untuk dapat meningkatkan kapasitas masyarakat, hal ini menekankan bahwa baik pendidikan formal dan non formal sangat diperlukan untuk mengubah sikap masyarakat (Desfandi, 2015).

Dari latar belakang diatas perlu adanya pembangunan karakter masyarakat Desa Mulyajaya agar lebih menjaga lingkungan. Dalam sejumlah observasi yang dilakukan dapat disimpulkan beberapa masalah pokok yang menjadi masalah di Desa Mulyajaya Kecamatan Lasalimu selatan Kabupaten Buton sekaligus hal-hal yang perlu dilakukan dalam membangun karakter masyarakat dalam perbaikan sanitasi lingkungan, yakni sebagai berikut:

1. Belum optimalnya pengetahuan masyarakat mengenai pentingnya Sanitasi Lingkungan.

2. Belum optimalnya sosialisasi kepada masyarakat perihal bagaimana menciptakan dan meningkatkan lingkungan yang sehat. 


\section{METODE}

Pengabdian masyarakat ini dilaksanakan melalui pendekatan modal sosial, sebab hal ini lebih mudah ditemukan dalam masyarakat yang lebih menonjol dalam ikatan budaya, kekerabatan dan lingkungan. Dengan begitu, pendekatan modal sosial memungkinkan adanya ikatan timbal balik dari dan kepada masyarakat lokal tersebut. Modal sosial sebagai perekat sosial (social glue) pada komunitas masyarakat. olehnya itu, modal sosial tersebut akan sangat ditentukan sebagai akumulasi dari beragam tipe dari aspek sosial, psikologi, budaya, kelembagaan, dan aset yang tidak terlihat (intangible) yang mempengaruhi perilaku kerjasama. Dengan deskripsi modal sosial seperti diatas, dipercaya bahwa pendekatan seperti itu dapat dijadikan salah satu sarana untuk mensosialisasikan Sanitasi Lingkungan kepada masayarakat. Melalui, kondisi masyarakat Desa Mulyajaya yang masih memegang erat kehidupan dan pengalaman budaya, serta kehidupan gotong royong masyarakatnya. Maka pendekatan budaya dan komunitas, memungkinkan adanya kolaborasi antara input kebijakan.

Modal sosial dimaksud sebagai metode pelaksanaan pengabdian masyarakat disini dapat diamati dalam pembentukan dan penguatan kelembagaan masyarakat lokal sadar lingkungan. Melalui tahapan Observasi, Wawancara Tokoh, dan Sosialisasi.

\section{HASIL DAN PEMBAHASAN}

Kegiatan PKM ini dilaksanakan oleh dosen Universitas Muhammadiyah Buton. Kegiatan pengabdian ini tidak hanya sebagai perwujudan tanggung jawab dosen untuk melaksanakan tanggungjawab dalam hal tridharma perguruan tinggi yang dilaksanakan rutin setiap tahun pada masyarakat. Kegiatan ini tentunya akan menambah wawasan sekaligus melengkapi keterampilan masyarakat. Tahapan Kegiatan Pengabdian Kepada Masyarakat (PKM) yang dilakukan adalah sebagai berikut:

1. Sosialisasi

Tahap sosialisasi program Sanitasi Lingkungan dilaksanakan di dibalai pertemuan Desa Mulyajaya, sosialisasi dialkukakan secara langsung oleh Tim PKM yang dihadiri oleh kepala Desa, Kepala Dusun, dan masyarakat Desa Mulyajaya.
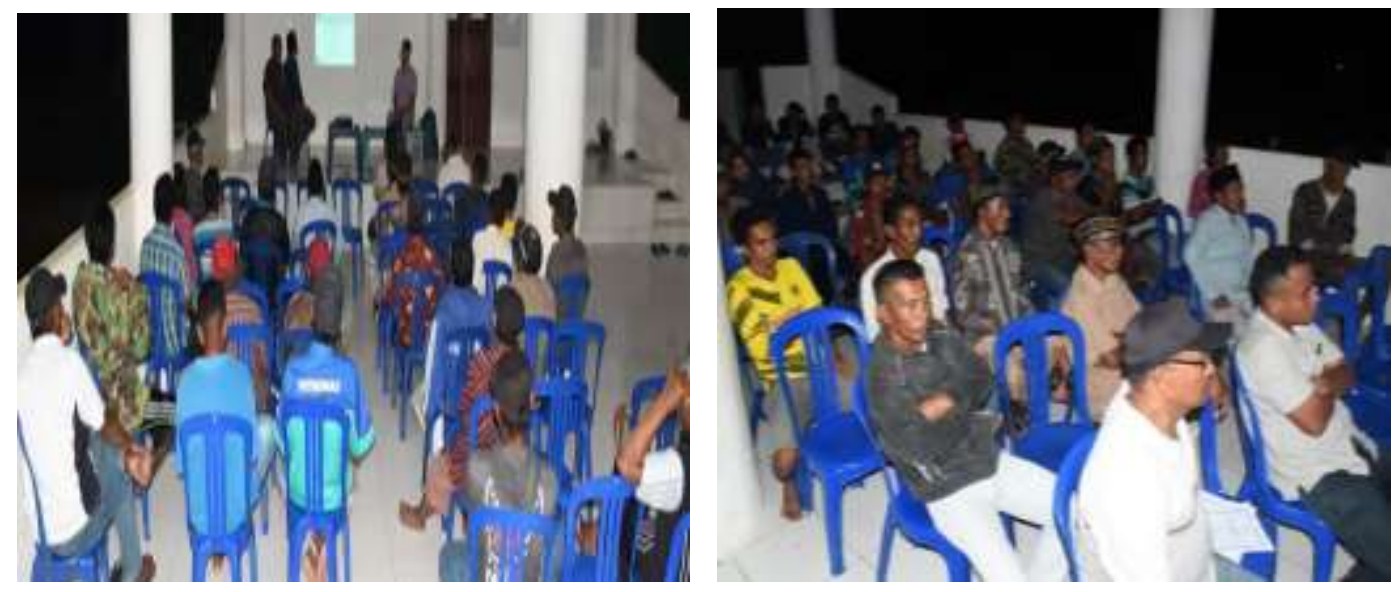

Gambar 3. Sosialisasi tentang sanitasi lingkungan

Sosialisasi tentang pentingnya Sanitasi Lingkungan yaitu stop buang sampah yang bukan pada tempatnya, jangan buang air besar sembarangan (membuat jaban dalam rumah). Kemudian pada tahap sosialisasi diberikan pemahaman tentang efek samping dari buang sampah yang bukan pada tempatnya dapat menimbulkan bau yang tak sedap untuk di hirup, menyebabkan wabah penyakit yaitu penyakit diare serta dapat menimbulkan banjir yang dikarenakan tersumbatnya saluran drainase. 
Efek buang air besar di sembarang tempat juga dapat menimbulkan berbagai penyakit berbahaya yaitu salah satunya penyakit ekoli (penyebab diare). sehingga dari sosialisasi ini dapat membangun kesadaran masyarakat agar tidak buang air besar di sembarang tempat dan menjaga lingkungannya tetap bersih atau masyarakat dapat berprilaku budaya hidup bersih dan sehat.

\section{Pendampingan}

Setelah diadakannya sosialisasi dilanjutkan dengan metode pendampingan yang mana kegiatan ini dilakukan pada masing-masing dusun dengan didampingi. Oleh Kepala Desa Mulyajaya dan kepala-kepala dusun, mereka semua diberikan penjelasan tentang tujuan di adakannya program sanitasi lingkungan yaitu agar terjadi perubahan prilaku sebagian masyarakat dari buang sampah yang bukan pada tempatnya serta pemahaman jangan buang air besar di sembarang tempat dengan menyentuh pola pikir, prilaku dan kebiasaan. Tujuan dilakukannya pendampingan untuk memotivasi masyarakat agar dapat merubah prilaku. Bila prilaku masyarakat sudah berubah maka anggota masyarakat tersebut akan membuang samapah pada tempat yang telah disediakan dan akan memiliki jamban di dalam lingkungan rumah sendiri. Prilaku yang bersih dan sehat dengan tidak mengotori lingkungan sekitarnya dengan menyentuh pola pikir, prilaku dan kebiasaan masyarakat.

\section{Perencanaan Pembuatan Tong Sampah dan Pembuatan Jamban}

Setelah diadakan pendampingan maka kegiatan selanjutnya adalah rencana tindak lanjut masyarakat untuk melakukan perubahan hidup sehat dan bersih yaitu dengan cara masyarakat tidak dibolehkan lagi membuang sampah yang bukan pada tempatnya dan buang air besar di sembarang tempat sehingga masyarakat diharuskan untuk membuat tong sampah dan jamban pribadi di masing-masing rumahnya. Semua masyarakat diharuskan untuk membuat dan menaruh tong sampah didepan rumah disetiap dusun agar setiap pagi dan sore hari petugas kebersihan lingkungan Desa Mulyajaya datang mengangkat sampah dan membuangnya pada tempat yang telah disediakan oleh pihak pemerintah desa.

Setelah itu kita bersama-sama mencari solusi rencana tindak lanjut dalam menentukan berapa biaya penyediaan tong sampah setelah itu membahas pembuatan jamban secara gotong royong. Bagi yang belum mampu untuk membuat WC dirumah kita memberikan solusi untuk merehap atau memberikan WC umum secara gotong royong yang telah disediakan oleh pemerintah desa agar layak untuk digunakan bagi masyarakat yang belum memiliki WC dirumah.

\section{KESIMPULAN}

Program pengabdian masyarakat ini menyimpulkan bahwa peran modal sosial dapat digunakan untuk masyarakat dalam bentuk pengetahuan lokal, yang kemudian dapat dimanfaatkan sebagai sarana mensosialisasikan pentingnya kesadaran sanitasi lingkungan. Proses meningkatkan pengetahuan masyarakat dalam perbaikan sanitasi lingkungan dilaksanakan melalui: sosialisai tentang sanitasi lingkungan kepada masyarakat, pendampingan dan Perencanaan Pembuatan Tong Sampah dan Pembuatan Jamban.

Dalam pelaksanaanya, pendekatan ini dipengaruhi oleh pengetahuan masyarakat, sarana dan prasarana pendukung program serta minimnya dukungan kesadaran terhadap dampak sanitasi lingkungan pada pendidikan masyarakat setempat.

\section{DAFTAR PUSTAKA}

Ismail, Asep Usman. 2010. Al-Qur'an dan Kesejahtraan Sosial, Tanggerang; Lentera Hati, cet-1 Notoatmodjo, Soekidjo. 2003. Pendidikan Dan Perilaku Kesehatan. Rineka Cipta. Jakarta.

Desfandi, M. (2015). Mewujudkan Masyarakat Berkarakter Peduli Lingkungan Melalui Program Adiwiyata. SOSIO DIDAKTIKA: Social Science Education Journal, 2(1), 31-37. 
https://doi.org/10.15408/sd.v2i1.1661

Prasanti, D., \& Fuady, I. (2017). Penyuluhan Program Literasi Informasi Kesehatan dalam Meningkatkan Kualitas Sanitasi bagi Masyarakat di Kaki Gunung Burangrang Kab. Bandung Barat. Jppm: Jurnal Pengabdian Dan Pemberdayaan Masyarakat, 1(2), 129. https://doi.org/10.30595/jppm.v1i2.1705

Purwanti, D. (2017). Pendidikan Karakter Peduli Lingkungan Dan Implementasinya. DWIJA CENDEKIA: Jurnal Riset Pedagogik, 1(2), 14-20. https://doi.org/10.20961/jdc.v1i2.17622

Rahman, H., \& Patilaiya, H. La. (2018). Pemberdayaan Masyarakat Melalui Penyuluhan Perilaku Hidup Bersih dan Sehat untuk Meningkatkan Kualitas Kesehatan Masyarakat. JPPM (Jurnal $\begin{array}{llll}\text { Pengabdian Dan } & 251 .\end{array}$ https://doi.org/10.30595/jppm.v2i2.2512

Rahmawati, D., Handayani, R. D., \& Fauzzia, W. (2018). Hygiene dan Sanitasi Lingkungan di Obyek Wisata Kampung Tulip. 1(1), 87-94.

Raksanagara, A., \& Raksanagara, A. (2016). Perilaku Hidup Bersih Dan Sehat Sebagai Determinan Kesehatan Yang Penting Pada Tatanan Rumah Tangga Di Kota Bandung. Jurnal Sistem Kesehatan, 1(1), 30-34. https://doi.org/10.24198/jsk.v1i1.10340

Ramadhani, M. R., Fernanda, R., Sari, R., \& Lubis, H. (2019). Peran Pola Asuh Orang Tua Dalam Membentuk Karakter Peduli Lingkungan. Psikostudia: Jurnal Psikologi, 7(2), 61. https://doi.org/10.30872/psikostudia.v7i2.2406

Suanta, M. (2016). Pengaruh Sanitasi Lingkungan Tempat Tinggal Dan Karakteristik Sosial Ekonomi Rumah Tangga Terhadap Terjadinya Diare Pada Balita Di NTT (Analisis Lanjut Data Susenas 2012). Bumi Lestari Journal of Environment, 16(2), 119. https://doi.org/10.24843/blje.2016.v16.i02.p05

Suryani, L., Aje, A. U., \& Tute, K. j. (2019). Pkm Pelatihan Kelompok Anak Cinta Lingkungan Kabupaten Ende Dalam Pegelolaan Limbah Organik Dan Anorganik Berbasis 3R Untuk Mengeskalasi Nilai Ekonomis Barang Sebagai Bekal Wirausaha Mandiri. Dinamisia: Jurnal Pengabdian Kepada Masyarakat, 3(2), 244-251. https://doi.org/10.31849/dinamisia.v3i2.3679 